\title{
Kommunikasiegebeure en prediking
}

\section{Antieke retoriek en moderne pragmatiek in die preekmaakproses}

\author{
C.C.A. Vrey \\ Dept. Klassieke en Semitistiek \\ Potchefstroomse Universiteit vir $\mathrm{CHO}$ \\ POTCHEFSTROOM
}

\author{
C.J.H. Venter \\ Dept. Diakoniologie \\ TSP / PU vir CHO \\ POTCHEFSTROOM
}

\begin{abstract}
The act of communication and preaching. Ancient rhetoric and modern pragmatics in the preparation of a sermon

From the hasic presupposition that preaching is God's act with people through his Holy Spirit, the authors imvestigate several applicable aspects from the field of ancient rhetoric and modern pragmatics. Attention is paid, imter alia, to the rhetorical sinuation, ancien rhetorical genres, the topor of an argumem and strategies for perswasion. These aspects are directly applied to the process of consirucing and delwering a sermon. In same vein way the authors uilize aspects indicated by modern pragmatics aspects such as the speaker, the hearer, time and space, and the shared knowledge berween preacher and hearer In conclusion, the urgent need for interaction between preacher and hearers in the preparation and delivering of a sermon is stated.
\end{abstract}

\section{Inleiding}

Daar mag gevra word watter voordele daar is vir 'n prediker om van die antieke retoriek en die modene pragınatiek kemnis te neem. Eerstens, die antieke retoriek is 'n sisteem wat ontwikkel is om gebruik te word by die maak van toesprake. Via Augustinus - wat van Cicero se sisteem gebruik gemaak het - het hierdie sisteem ook in die kerk 'n plek gekry. Is 'n preek nie ook maar in 'n sekere sin 'n toespraak nie? Tweedens, die modeme pragmatiek is 'n sisteem wat gebruik kan word om te bepaal of die taalgebruik in die preek effektiewe kommunikasie daarstel aangesien 'n prediker tog effektief in sy preek wil kommunikeer

In 'n artikel oor die retoriek, retoriese analise en die prediking het Du Toit (1992) 'n 'nuwe' invalshoek vir die preekmaakproses bekendgestel en het hy die waarde van die antieke retoriek vir die prediking aangetoon. In hierdie artikel word daar 
noue aansluiting by Du Toit (1992) gevind. Daar word egter ook verder gegaan deur die gebruikmaking van die moderne pragmatiek saam met die antieke retoriek vir die preekmaakproses te verken. Slegs die tersaaklike insigte vanuit die antieke retoriek wat Du Toit nie aan die orde stel nie, word in hierdie artikel uiteengesit.

Ontwikkelinge in die kommunikasieproses in die prediking - onder andere Dingemans (1991) en Pieterse (1992) - wys op die aktiwiteite van die hoorder in die prediking. Uit dié studies word dit duidelik dat die prediker 'n groot verantwoordelikheid het om ook die hoorders van die preek in die preekmaakproses in 'n groter mate in ag te neem.

In aansluiting by bogenoemde navorsing word in hierdie artikel van die standpunt uitgegaan dat prediking 'n kommunikasiegebeure is. In die preek moet die werklikheid van die lewende Woord die hoorders hier en nou in hulle werklikheid aanspreek. Die Woord moet die hoorders deur middel van die preek aangryp, sodat die hoorders via die preek deur die Woord verander kan word.

'n Prediker het net woorde om die Woord aan die mense van vandag te bedien (Bingle, 1986:75). Die geroepe prediker moet daarom nie net met die eksegese en hermeneuse vir die preek erns maak nie, maar hy het ook die verantwoordelikheid om hierdie eksegese en hermeneuse duidelik en verstaanbaar aan die mens van sy tyd bedien. Die hipotese vir hierdie artikel is dat die antieke retoriek en die moderne pragmatiek waardevolle bydraes tot die kommunikasiegebeure van die prediking kan lewer.

Hoewel die antieke retoriek en die moderne pragmatiek waardevolle bydraes tot die preekmaakproses lewer, moet dit onthou word dat die prediking steeds God se eie handeling met mense deur sy Gees bly. In die lig van hierdie stelling behoort die prediker sy oortuiging onder die beheersing van die Gees te stel. Dit kan en moet die prediker alleen doen deur gedurig onder gebed in die preekmaakproses te verkeer. Trouens, net die Heilige Gees kan die lewende Woord van God ' $n$ werklikheid in die hoorders se lewensituasies maak.

\section{Antieke retoriek en prediking}

\subsection{Inleiding}

Retoriek kan gedefinieer word as die vermoë om vir enige onderwerp die geskikste oortuigingsmiddele te vind, en die oortuigingsmiddele op 'n effektiewe wyse te kommunikeer om sodoende die gehoor te oorreed. Argumentvoering is ' $n$ rasionele, verbale vorm van sosiale interaksie wat 'n definitiewe begin en einde het en wat ten doel het om te oorreed (Vorster, 1991:52). Deurdat argumentvoering ' $n$ rasionele, verbale vorm van sosiale interaksie genoem word, word dit 
midde in die gespreksituasie geplaas. Ondat 'n preek ten doel het om te oorreed, kan dit ook as 'n sosiale interaksie beskou word: 'n sosiale interaksie gerig tot 'n spesifieke sosiale groep - die gelowiges.

Daar is ook elemente van tyd en rumte in argumentvoering betrokke. Daarby is daar ook 'n spreker en 'n hoorder betrokke, en ondat die spreker en die hoorder oor gedeelde kennis beskik, is die argumentvoering vir hulle duidelik en verstaanbaar. Die enigste verskil tussen 'n argumentvoering en 'n gewone gesprek is dat eersgenoende dikwels in die afwesigheid van die hoorder voorberei word, terwyl laasgenoemde spontaan tussen die twee persone ontwikkel. Daarom is dit duidelik dat 'n argumentvoering 'n spesifieke vonn van interaksie is. Argumentvoering kan nogtans nie substantief wees nie. Iemand moes iets gedoen of gesê het wat aanleiding gegee het tot die ontstaan van 'n argumentvoering; met ander woorde argumentvoering is interaksioneel (Vorster, 1991:56). In die geval van 'n preek kan iets wat onder of met die sosiale groep gebeur het, lei tot die maak van 'n spesifieke preek.

Dit bring 'n mens by die vraag na die causa of quaestio van die argument, naamlik die daad of uiting wat aanleiding gegee het tot die argumentvoering. Anders gestel, die argumentvoering is 'n respons op 'n situasie, ook genoem die retoriese situasie, waarin een of ander behoefie aanwesig is

\subsection{Die retoriese situasie, status-leer en 'n preek}

Die retoriese situasie is 'n samestelling van persone, gebeure, doelwitte en relasies wat in die argumentvoering neerslag vind. Hierdie samestelling is die prediker se perspektief op die historiese situasie waarin sy hoorders verkeer. Die vraag is nou hoe die retoriese situasie in 'n preek kan lyk.

Wanneer 'n mens 'n preek maak, is dit van groot belang dat die status bekend moet wees. Die status is immers die vraag waarop die preek as argumentvoering 'n respons is. Dit is moontlik om gedeeltelik met behulp van die gespreksituasie (kyk \$3.2) die retoriese situasie te omskryf (Vorster, 1991:53). Die oorsaak (causa) wat vroeër (kyk \$2.1) genoem is, konkretiseer die behoefte van die retoriese situasie. Dit (causa) domineer die retoriese situasie en bepaal ook die status van die argumentering. Dié cuusa mag verander soos wat die argumentvoering vorder. Hierdie verandering van die causa kan teweeggebring word deur 'n moontlike situasieverandering by die hoorders as gevoly van die oorreding in die preck tot op 'n spesifieke punt. Wanneer die causa verander, verander die status van die argumentvoerng. Aan die ander kant bepaal die status van die argument weer die genre van die argument

Die status wat telkens hier genoem is, is afkomstig van die status-leer van Hermagoras. In boek 7 van sy De Instrtulione Oratorla gee Quintilianus 'n uitgebreide bespreking van Henmagoras se starus-leer. Deur middel van 'n aantal vrae 
wat die spreker aan homself vra, neem hy elke omstandigheid en moontlike ontwikkeling van die saak in ag (De Institutione Oratoria, 7, Pr., 4). Opsommend kan die status-leer soos volg uiteengesit word:

* Status coniecturae: Daar bestaan twyfel oor die feite en die spreker vra of so 'n daad waarvan die beskuldigde aangekla word, wel bestaan.

* Status definitionis: Nadat daar duidelikheid oor die feite verkry is, moet die daad wat deur die aangeklaagde gepleeg is, gedefinieer word.

* Status qualitatis: By die verdediging van die aangeklaagde en ter versagting word daar gevra of die daad wat gepleeg is, nie dalk regverdigbaar is nie.

* Status translationis: Indien die daad nie geregverdig kan word nie, bestaan daar 'n ander moontlikheid, naamlik om die skuld op iemand anders oor te dra. Anders moet daar erken word dat die aangeklaagde onkundig was, of die voordele van die daad moet teen die nadele daarvan opgeweeg word.

Die status-leer van Hermagoras is hoofsaaklik vir juridiese redevoering ontwerp; daarom moet die nodige aanpassings gemaak word met betrekking tot die spesifieke vrae vir die status van 'n preek. Preke val nie uitsluitlik in die juridiese genre nie (kyk §2.3).

Binne die retoriese situasie moet die causa waarop die status van die preek 'n antwoord moet wees, bekend wees. Die causa is die prediker se perspektief van dit wat onder of met die sosiale groep gebeur het en wat gelei het tot die maak van die preek. Hierdie gebeure plaas die hoorders in 'n spesifieke situasie. In hierdie situasie het hulle bepaalde vrae wat hulle beantwoord wil hê. Die ondersoek van hierdie vrae en die situasie van die hoorders is reeds deel van die statusbepaling van 'n preek; daarom kan die situasie van die hoorders tot 'n spesifieke tekskeuse lei.

Die status-bepaling van 'n preek bestaan in der waarheid uit twee dele. Die een deel is die bepaling van die status van die argument in die teks van die Skrif. Hierdie deel van die status-bepaling word by die eksegetiese arbeid gedoen. Die status van die Skrifteks en die status van die preek moet egter op 'n organiese wyse by mekaar aansluit. Die status van die Skrifteks is die vraag waarop die spesifieke argument van die Bybelskrywer 'n antwoord is. Hierdie ondersoek na die status van die Skrifteks is deel van die vind van argumente uit die primêre Bron. Die ander deel van die status-bepaling van 'n preek is die ondersoek na die situasie en vrae van die hoorders. In hierdie artikel word daar spesifiek op hierdie deel van die status-bepaling gekonsentreer.

Die twee dele van die status-bepahing is met mekaar vervleg. Daarmee word bedoel dat die een deel nie van die begin tot die einde eers afgehandel word voordat daar met die ander deel begin word nie. Prakties lyk dit of daar met die status-bepaling begin word by die hoorders se situasie en dan word daar 
oorgegaan na die status-bepaling uit die Skrifteks. Die twee dele word in 'n sekere sin ook in gelyke mate gehanteer, maar tog onderskeie van mekaar. Om die situasie van die hoorder te bepaal, is daar verskeie sake waarvan die prediker bewus moet wees.

Daar is reeds opgemerk dat die status van die argument ook die genre van die argument bepaal. Dit beteken dat die vraag waarop die preek 'n antwoord moet wees, die genre van die preek gaan bepaal. Die verskillende genres van die antieke retoriese sisteem mag moontlik lig werp op die preekmaakproses en daarom word dit hier bespreek.

\subsection{Antieke retoriese genres en die 'genre' van 'n preek}

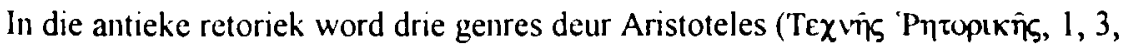
1-5), Cicero (De Partitione Oratoria, 3, 10-4, 11) en Quintilianus (De Institu-

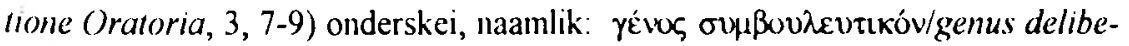
ranivum ('n toespraak oor samelewingsaangeleenthede, byvoorbeeld politieke

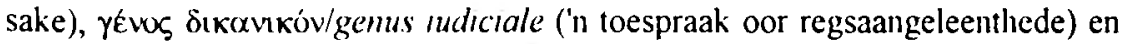

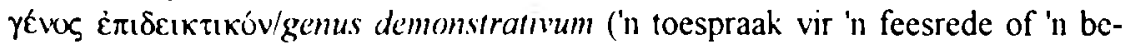
grafnisrede). Omdat Du Toit (1992:466) hierdie genres breedvoerig bespreek, word dic genres in die onderhawige artikel slegs genoem

Hierdie antieke retoriese genres dek 'n wye veld. Venter (1992:6-10 en 1993: 252) bespreek verskillende kommunikasiegestaltes van die Woordbediening. In aansluiting by die antieke retoriese sisteem kan hierdie kommunikasiegestaltes 'genres' genoem word. Dié 'genres' is meer spesifiek binne die drie groot antieke retoriese genres. Hierdie 'genres' is $\delta 1 \delta \alpha \sigma \kappa \alpha \lambda i \alpha$ (om instruksies in 'n formele en informele opset te gee), $\dot{\varepsilon} \varepsilon \gamma \chi \alpha{ }^{\prime}$ (streng teregwysing teenoor iemand wat verkeerd gedoen het waarvoor daar genoegsame bewyse is vir die verkeerde

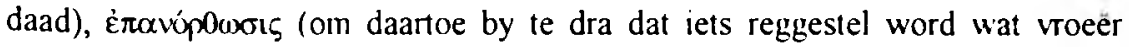
verkeerd was), $\pi \alpha i \delta \varepsilon i \alpha$ (om instruksies te gee met die doel om die regte ge-

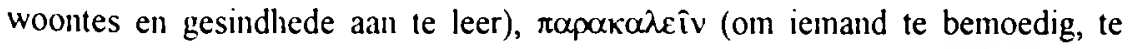
venmaan of te vertroos), $\pi \alpha p \alpha \gamma \gamma \varepsilon \lambda \lambda \varepsilon i v$ (om dringend aan te kondig wat gedoen

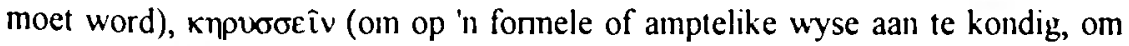
openlik en uitgebreid aan te kondig en om openlik godsdienstige waarhede en

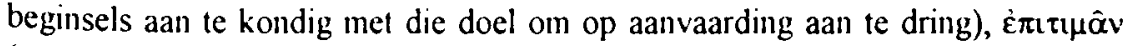
(om sterk afkeer van iemand uit te druk) en hadeîv (om te praat, moontlik met die implikasie van 'n infonnele gesprek). Hierdie genoende 'genres' kan onder enige

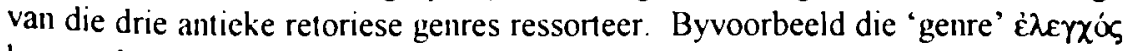
kan onder die juridiese genre ressorteer waarin daar tor 'n groot mate van aanklaende taal gebruik gemaak word. Hierdie 'genre' kan ook onder die deliberatiewe genre ressorteer indien die prediker nie net aanklaend nie, maar ook vermanend preek on sodoende 'n verbetering in die lidmate se optrede teweeg te bring. 
Nadat die status van die Skrifteks en daarmee saam die retoriese situasie van die argument in die Skrifteks bepaal is, kan die genre van die argument in die Skrifteks bepaal word. Indien die causa wat uit die situasie van die hoorders verneem is en die status van die Skrifteks oorvleuelend is, kan die 'genre' van die preek as argument vorm aanneem. Die 'genre' van die preek as argument kan - maar hoef nie - met die genre van die argument in die Skrif ooreenstem.

In aansluiting by die 'genres' wat Venter (1992 en 1993) aandui, kan 'n preek een of meer van die volgende 'genres' of funksies hê: lerend of onderrigtend, teregwysend, bemoedigend, vermanend, vertroostend, amptelik aankondigend en afkeurend. Die genre van die argument in die Skrifteks kan ook 'n leidende rol speel by die keuse van die funksie van die preek, hoewel die prediker se doel met die preek ' $n$ bepalende rol by die aard van die preek speel. Dit is egter so dat 'n preek moontlik meer as een funksie kan hê, omdat die prediker met die voorbereiding van die preek tot ' $n$ veronderstelde besluit kon kom. Trouens, 'n verantwoordelike prediker kan tog nie net straf verkondig nie. Hy moet ook die troosryke genade van die regverdige God verkondig.

Die veronderstelde besluit waartoe die prediker kon kom, word bepaal deur vrae wat hy homself afvra namate die preekhandeling vorder. Dit is vrae na 'n moontlike besluit waartoe die hoorders kon gekom het wanneer hulle tot by 'n spesifieke punt geluister het. Daarom verander die causa van die implisiete hoorders namate die oorreding in die preek vorder.

Die verskillende genres bepaal ook die mees geskikte topoi wat in 'n toespraak gebruik behoort te word. Daarom help die status en die topor ook om die genre van die argument van 'n preek te kies.

\subsection{Die topoi van die argument en van 'n preek}

Topoi moet nie met topics verwar word nie. Die topos van 'n argument is, simplisties gestel, die taktiese maneuvers wat die persone in die retoriese situasie gebruik (Van Eemeren \& Grootendorst, 1987:65). Cooper (1960:15) vertaal dié term met "lines of argument". Anders gestel, topoi is die vooronderstellings (premisse) van die persone wat betrokke is in die retoriese situasie - vooronderstellings wat soms eksplisiet, maar in die meeste gevalle implisiet in die argument ingebed is (Van Eemeren \& Grootendorst, 1987:225). Die vooronderstellings behoort in noue samehang te wees met die waardes van die gemeenskap van gelowiges tot wie die preek gerig word.

Vorster (1991:66) stel dit ook dat die topoi 'n respons op die retoriese situasie is. Indien die spreker effektief wil argumenteer, moet die topoi by die hele argument pas. Die resultate van die keuse van die topol, gekombineer met die keuse van die status kan die prediker help met die betrek van die behoefte van die situasie. 
Hieruit blyk die verhouding wat daar tussen die status en topol van 'n argument bestaan.

Ter illustrasie van topoi kan gemeld word dat daar in 'n deliberatiewe rede (genus deliberativum - 'n toespraak oor samelewingsaangeleenthede) ' $n$ algemene topos aanwesig behoort te wees. Hierdie topos is die vergelyking van die mate van

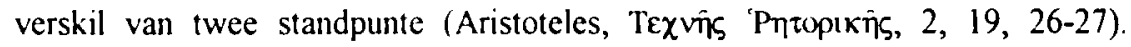
Onder hierdie algemene topos is daar vier spesifieke topoi wat direk met die deliberatiewe rede verband hou:

* Die eerste een is om op grond van die gevolge van teenoorgestelde koerse

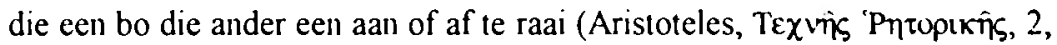
$23,14)$.

* 'n Tweede spesifieke topos geld vir sowel die juridiese as die deliberatiewe rede. Dit is om die aansporings en ontmoedigings te bepaal wat as motiewe vir mense dien om iets te doen of te vermy. Dit wat moontlik, maklik en

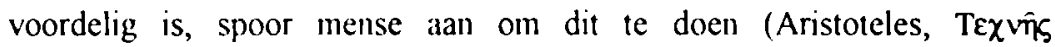
'Pnтopikñs, 2, 23, 21)

* Die derde topos wat hier genoen kan word, is om te bepaal of daar ' $n$ beter

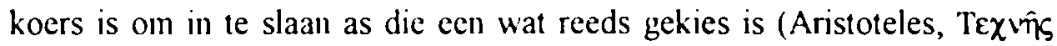

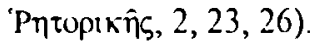

* 'n Laaste topos is om die voorgestelde koers inet die vorige of huidige koers

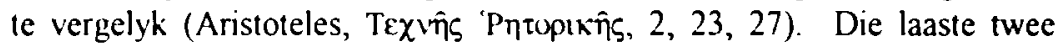
topoi hou sterk met mekaar verband.

Hierdie ropoi kan ook met die nodige aanpassings in 'n preek gebruik word,

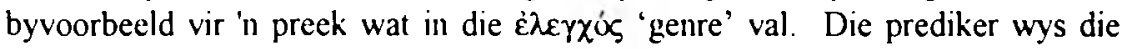
hoorder tereg op die verkeerde daad, maar hy kan ook van die derde en vierde topos hierbo gebruikmaak om 'n beter koers aan te dui.

Uit bogenoemde word dit duidelik dat die verskillende 'genres' die mees geskikte topoi van die argument bepaal. In 'n preek behoort dit op dieselfde wyse te werk Ondat nie een spesifieke 'genre' van die preek in hierdie artikel bespreek word nie, word daar ook nie verder oor die topoi van 'n preek gehandel nie. Dit moet wel in gedagte gehou word dat die topoi wat gekies word, by die 'genre' moet pas en dat dit hoofsaaklik geloofswaarhede is wat nie beredeneer hoef te word nie. Geloofswaarhede soos dit in die belydenisse saamgevat is, kan as topoi vir die preek dien. Die topo is natuurlik afhanklik van die hoorders se geloofstand of -agterstand.

Nadat die status en topot vir die preek gekies is, kan die gepaste oortuigingsmiddele vervolgens gekies word. 


\subsection{Oortuigingsmiddele}

Die oortuigingsmiddele waarvan 'n antieke spreker gebruik kon maak, val in twee dele uiteen, naamlik tegniese en nie-tegniese oortuigingsmiddele. Nie-tegniese oortuigingsmiddele sluit in wette, getuies, kontrakte en ander dokumente,

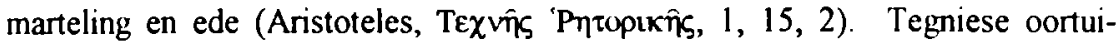

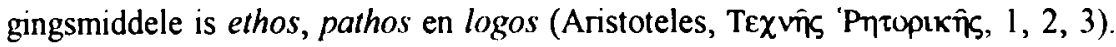
Wanneer die spreker van ethos gebruik maak, het hy ten doel om hoinself by die gehoor geloofwaardig te maak. Mense luister immers eerder na iemand wat geloofwaardig is as andersins. Die spreker maak van pathos gebruik wanneer hy die gehoor se emosies wil beïnvloed, aangesien ' $n$ mens se oordeel oor 'n saak saamhang met blydskap of hartseer en liefde of haat. Die laaste middel, naamlik logos, is die logiese aanbieding van die argumente.

Voordat die gebruik van die oortuigingsmiddele in 'n preek bespreek gaan word, is dit nodig om die volgende te beklemtoon, omdat dit immers vir die hele kommunikasiegebeure geld: God neem die prediker in sy hele menswees in beslag. Hy gee aan hom die vermoens en kragte om sy Woord aan mense te bedien. Hierdie bediening moet op ' $n$ verantwoordelike en effektiewe wyse plaasvind. (Hierdie stellings sal weer aan die einde van dié paragraaf aan die orde gestel word.)

Logos is bestempel as die oortuigingsmiddel wat die logiese aanbieding van die argumente aandui. Die onderskeie onderafdelings en sinne van 'n preek moet logies in mekaar verweef wees. Die prediker moet in gedagte hou dat die hoorders die preek die eerste maal hoor en dit is waarskynlik ook die laaste maal. Indien die hoorder nie ' $n$ volgstuk van die preek voor hom/haar het nie, het die prediker soveel meer die verantwoordelikheid om sy preek logies te struktureer. Die hoorders mag nie 'verloor' word in die verkondiging van die Woord nie. Indien die hoorder as gevolg van 'n nie-logiese preek verloor word, kommunikeer die prediker nie effektief nie. Die volle strekking van die Skrifteks kan die hoorder dan nie behoorlik aangryp soos dit moet gebeur nie. Nie alleen moet die onderskeie punte logies in mekaar verweef wees nie, die onderskeie argumente en die topoi wat die prediker gebruik, moet ook logies wees. Indien argumente nie logies op mekaar volg nie, kan dit tot absurde gevolgtrekkings by die hoorder lei. Hierdie gevolgtrekkings mag ook die prediker se ethos skade aandoen, want dit mag vir die hoorder voorkom of die prediker nie sy werk behoorlik gedoen het nie.

Wanneer die prediker deur die hoorders as geloofwaardig beskou wil word, maak hy gebruik van ethos. In 'n preek is dit natuurlik die Here God wat deur die prediker aan die woord moet wees. Trouens, God is die eintlike Kommunikator in die preek. Die feit dat die preek egter tot mense gerig word - mense wat sondaars is - wat met bepaalde vooroordele na die prediker kán luister, noodsaak dat ethos ook in die preek 'n plek moet kry. Die prediker kan ethos laat neerslag vind 
in sy persoonlikheid. Daarmee word bedoel dat hy sy nederigheid, liefde, empatie en gemeensaamheid met die hoorders deur sy totale optrede kan laat blyk. 'n Prediker bevorder nie alleen sy ethos in 'n preek nie, maar dit word ook gebou of afgebreek deur sy optrede van Maandag tot Saterdag. Dié eienskappe, soos liefde en nederigheid, behoort ook in sy woorde en die wyse waarop hy dit in die preek kommunikeer na vore te kom. Indien die prediker die Woord so verkondig dat hy aan die hoorders toon dat die Woord hom ook geraak het, bevorder hy sy ethos in die preek. Die feit dat die prediker aantoon dat die Woord hom ook geraak het, sluit baie nou aan by die derde oortuigingsmiddel, naamlik pathos.

Pathos is die oortuigingsmiddel waannee die prediker die emosies van die hoorders so beïnvloed dat hulle die rigting kies wat hy graag wil hê hulle moet volg. Die prediker moet met die gebruik van pathos veral in die preek baie seker maak wat hy daannee wil bereik. 'n Onoordeelkundige gebruik van dié middel kan tot 'n vertonery lei wat nie by 'n ware gelowige prediker pas nie. Aan die ander kant kan die oordeelkundige gebruik van pathos baie bydra tot die effektiewe kommunikasie in die preek. Om veilig om te gaan met pathos kan die prediker sy pathos by diè van die Skrifteks laat aansluit. Sodoende bly die prediker ook in hierdie saak aan die Skrif getrou. Die prediker moet uitdrukking gee aan die emosies wat hy graag by die hoorders wil aanwakker. Indien dit nie gebeur nie, is die gebruik van pathos van geen waarde in die preek nie. In aansluiting by die belydenis dat geloof ' $n$ gewisse kennis en 'n vaste vertroue is, kan pathos juis die funksie vervul om die vertroue aan te wakker. 'n Wyse waarop die prediker van pathos gebruik kan maak is die volgende: hy kan sy woorde en stem op so 'n wyse gebruik dat hy sy hoorders getref deur die Woord kan laat voel, op 'n soongelyke wyse as wat hy getref is deur die Woord. Eenvoudig gestel: die hoorder moet ook 'n knop in die keel kan voel, omdat die prediker 'n knop-in-diekeel kommunikeer.

Om terug te keer na die stellings wat vroeêr in die paragraaf gemeld is, is dit nodig om die volgende te sê as samevatting op die bespreking van die oortuigingsmiddele. God lê op die rasionele en emosionele aard van die prediker beslag. Hierdie beslaglegging noop die prediker om met sy eie geaardheid die Woord te bedien. Omdat hy die Woord aan mense moet bedien, kan hy dit nie op 'n kil meganiese wyse doen nie. Hy praat nie met masjiene nie, maar met mense met persoonlikhede en unieke geaardhede; dus lyk dit verantwoordelik om juis van die drie genoemde oortuigingsmiddele gebruik te maak. Sodoende is die bediening nie net verantwoordelike bediening van die Woord nie, maar ook effektiewe bediening.

In aansluiting by die retoriese situasie is die gespreksituasie in die preek ook van belang. Daarom kom die insigte vanuit die moderne pragmatiek met die toepassing daarvan vervolgens aan die orde. 


\section{Die moderne pragmatiek en die prediking}

\subsection{Inleiding}

Leech definieer pragmatiek as "the study of how utterances have meanings in situations" (1983:x), "how language is used in communication" (Leech, 1983:1). Pragmatiek kan aangewend word om die mees effektiewe kommunikasie in die preek te bewerkstellig. ' $n$ Gesprek is ' $n$ interaksie tussen mense en die interaksie word selfs in 'n preek teenwoordig gestel. Daar is reeds opgemerk dat 'n preek nie 'n kil voordrag van die waarhede van God moet wees nie (kyk \$2.5). Verder is reeds daarop gewys dat ' $n$ redenaar in die voorbereiding van sy toespraak homself moet afvra tot watter konklusies die hoorder kon kom ten opsigte van dit wat reeds gesê is en watter moontlike vrae daar by die hoorder kan opkom (kyk §2.3). Dit is dus geregverdig om aan te neem dat 'n prediker ook in die voorbereiding van sy preek in gesprek is met die mense tot wie die preek gerig gaan word.

Om te bepaal of ' $n$ uiting effektief gekommunikeer word, is dit nodig om by die groter geheel te begin, naamlik die gespreksituasie waarin die uiting voorkom. Dit is dus nodig dat die aard van die verhouding tussen die spreker en die hoorders vir die prediker duidelik moet wees. Die aard van dié verhouding kom na vore uit die hele konteks waarin die spreker en hoorders hulle bevind.

\subsection{Die gespreksituasie}

\subsubsection{Inleiding}

Die gespreksituasie moet nagegaan word ten opsigte van die aspekte van persone, tyd, ruimte en gedeelde kennis. Sodoende word dit moontlik om die interaksie wat in die preek teenwoordig is, eksplisiet te maak.

Die inligting wat uit die bestudering van die gespreksituasie in 'n preek verkry word, kan die prediker help om te bepaal of hy effektief kommunikeer. Die bestudering van die gespreksituasie word gedoen aan die hand van deiktiese elemente, soos voornaamwoorde en woorde wat op tyd en ruimte dui.

\subsubsection{Die spreker}

Anders as wanneer 'n skriftelike teks ondersoek word, is daar in die preek in der waarheid twee geènkodeerde sprekers. Dié twee sprekers is in die eerste plek God en in die tweede plek die prediker self. Die geënkodeerde sprekers word deur sekere 'spore' in die teks gemanifesteer Hierdie 'spore' is deiktiese elemente waarmee die geënkodeerde spreker na homself verwys. In die geval van 'n preek is dit in die meeste gevalle 'Ek, die Here' of 'ek, die prediker'. In I Korin- 
tiërs 7 is daar 'n voorbeeld waar die geënkodeerde (P)prediker(s) op hierdie wyse afgewissel word tussen die Here en Paulus.

In 'n preek moet die prediker God as die eintlike Spreker in die preek aan die woord laat kom. Op hierdie manier is die prediker geloofwaardig vir die hoorders. Om weer eens by Paulus aansluiting te vind, lyk dit geregverdig om te sê dat die 'spore' van die Spreker en die 'spore' van die prediker duidelik van mekaar onderskei moet word (vergelyk 1 Korintièrs 7). Sodoende kan daar verhoed word dat die prediker aan sy woorde dieselfde gesag verleen as die woorde van die Spreker. Hierdie stelling word gemaak veral met die oog op die toepassing van die Skrifbeginsel in die preek.

\subsubsection{Die hoorder}

Net soos by die spreker is daar in die preek ook twee implisiete hoorders teenwoordig. Dié twee hoorders is die prediker self in die eerste plek, en in die tweede plek die mense tot wie die preek gerig word. Die deiktiese elemente waardeur die implisiete hoorders aangespreek word, is 'jy', 'julle' of 'ons'. Die implisiete hoorders word ook bekend deur frases wat die geënkodeerde sprekers aanwend om die hoorders mee an te spreek. Violi (1985:152) meld dat die implisiete leser van ' $n$ brief baie spesifick is, met ander woorde 'n spesifieke individu of 'n bepaalde groep lesers. Hierdie saak moet in die preekmaakproses enstige aandag geniet. Die prediker moet sy hoorders ken. Die kennis wat die geënkodecrde spreker oor die implisiete hoorders se kemnis en vaardighede het, staan bekend as gedeelde kemnis $(\$ 3.2 .5)$.

Perelman en Olbrechts-Tyteca (1969:19) bestempel die implisiete leser as diè persoon vir wie die outeur met sy argumente wil oorreed. In 'n preek is dit natuurlik die implisiete hoorders wat deur die geenkodeerde sprekers oorreed moet word

Hoewel die situasie van die hoorders 'n baie belangrike rol in die preeknaakproses speel, bepaal dit me die uitleg van die Skrif nie, maar wel die kommunikasie van die uitleg van die Skrif. Aangesien die wyse van kommunikasie verander moet word op grond van die aard van die hoorders van die preek en hulle situasie, is die volgende sake van belang. Die prediker moet saam met die bepaling van die oorspronklike causa in gedagte hou wat die geslag van die hoorders is, hulle ouderdomsgroep en veral ook hulle geloofstand of geloofsagterstand. Hierdie drie sake gaan egter nie net 'n invloed op die oorspronklike causa hê nie. Hierdie sake is ook bepalend vir die woord- en taalgebruik in die preek. Bingle (1986) het breedvoerig ingegaan op die woord- en taalgebruik in die preek en diè aspekte word dus nie hier bespreek nie.

Wat wel ter sake is vir hierdie artikel is dat die drie genoemde sake ook in beslissende invloed het op die moontlike vrae wat die hoorders gedurende die 
preek mag hê. Soos hierbo (kyk \$2.3) getoon word, is dit die vrae wat die prediker homself moet afvra gedurende die preekmaakproses. Die vrae is bepalend vir die tipe argument wat die prediker gaan gebruik en hoe hy dit effektief gaan kommunikeer. Effektiewe kommunikasie is ook afhanklik van die gebruik van oortuigingsmiddele (kyk §2.5).

Dit is alreeds gemeld dat ' $n$ brief tot ' $n$ spesifieke individu gerig word. Hierdie feit is ook op die preek van toepassing; daarom is dit noodsaaklik dat die prediker homself moet vergewis van wie die hoorders van die preek is. Dit noodsaak die prediker ook om die hoorders behoorlik te ken, sodat hy kan weet watter vrae hulle kan vra. Elke hoorder het immers 'n eie unieke situasie wat ook in ag geneem moet word. Met hierdie kennis - vanuit sy eie perspektief - tot sy beskikking kan die prediker die hoorders effektief bereik in die preek. Die effektiwiteit is afhanklik van sy opsomming van die hoorders.

Aangesien daar in die preek in der waarheid twee hoorders is, naamlik die lidmate sowel as die prediker, moet albei in die preek figureer. Die wyse waarop die prediker as hoorder in die preek optree, kom veral na vore in sy aanduiding dat die Woord hom geraak het, waardeur die solidariteit tussen die prediker en sy hoorders aangedui word. Hierdie solidariteit kan met behulp van die oortuigingsmiddele ethos en pathos bereik word (kyk \$2.5).

\subsubsection{Die tyd en ruimte}

In 'n preek is daar hoofsaaklik twee tydsdimensies ter sprake. Die eerste tydsdimensie is dié van die Skrifteks wat as primêre Bron vir die preek dien. Die tweede tydsdimensie is dié van die preek. Die twee tydsdimensies kan kortom soos volg benoem word: die tyd van die primêre Bron is die 'toe' in die preek en die tyd van die hoorders is die 'nou' in die preek. Die twee benoemde tye ('toe' en 'nou') is die twee deiktiese elemente wat prominent in 'n preek funksioneer.

Net soos by die aspek van tyd is daar hoofsaaklik twee ruimtelike dimensies wat in 'n preek funksioneer. Die eerste ruimtelike dimensie is die ruimte van die Skrifteks wat as primêre Bron vir die preek dien. Die tweede ruimtelike dimensie is die ruimte van die preek. Dié twee dimensies kan kortom soos volg benoem word: die ruimte van die primêre Bron is die 'daar' in die preek en die ruimte van die hoorders is die 'hier' in die preek. Die twee benoende ruimtelike dimensies ('daar' en 'hier') is die twee deiktiese elemente wat prominent in 'n preek funksioneer.

Sowel die werklikheid van die Woord as die werklikheid van die lidmate moet ernstig bejeën word deur die prediker wanneer hy 'n preek maak (Pieterse, 1992:326). Verder, die Woord en die werklikheid moet nouer op mekaar betrek word sonder om die primaat van die Woord prys te gee (Pieterse, 1992:335). Hierdie twee baie belangrike sake wat Pieterse aanstip, lê swaar op die skouers 
van die prediker. Hy moet die tyd en ruimte van die Skrifteks ('toe daar') en die tyd en ruimte val die hoorders ('nou hier') op die brug van herneneuse in wisselwerking laat kom.

'n Wyse waarop hierdie wisselwerking effektief in die preek kan plaasvind, is deur die hoorders saam te neem 'in' die Skrifteks 'in'. Dit kan alleen gebeur indien die prediker self al 'daar' was in sy voorbereiding.

Met die bewustheid daarvan dat die prediker slegs ' $n$ instrument van die Here is, maar dat hy tog die verantwoordelikheid het om die Woord effektief te kommunikeer, kan die volgende voorstel gemaak word. Die preek behoort saangestel te wees soos 'n verhaal wat gelees word. Die volgende word daarmee bedoel: die leser moet in die teks ingaan en met die karakters en gebeure in die teks in interaksie 'tree', sodat wanneer hy die verhaal klaar gelees het, hy nie onaangeraak gelaat is me. Om hierdie stelling op 'n preek toe te pas: 'n prediker het die verantwoordelikheid on die hoorders van die preek deur die preek 'in' die Skrifteks 'in' te begelei. In hierdie begeleidingsproses moet die prediker die hoorders aan die 'karakters' in die Skrifteks bekendstel en hom/haar aan die gebeure in die Skrifteks laat deel hê. Sodoende begelei die prediker die hoorders na die tyd en rumte ('toe daar') van die Skrifteks en vind daar interaksie tussen die hoorders en 'karakters' en gebeure (dit wat God doen) van die Skrifteks plaas. Daar mag nou gevra word of dit regverdig is on so 'n voorstel te maak. Tog het Paulus dit immers gedoen. In sy brief aan die Galasièrs sê hy dat hy Jesus Christus op so 'n wyse aan hulle (die Galasiërs) verkondig het dat hulle Jesus Christus as't ware aan die kruis kon sien hang (Galasiërs 3:1).

Deurdat die prediker die hoorders 'in' die Skrifteks 'in' begelei, bestaan die vertroue dat die hoorders deur die interaksie die beginsel van die Skrifteks duideliker sal kan verstaan. Deur iniddel van hierdie interaksie kan daar nou in die preek op 'n organiese wyse van die 'toe daar' na die 'nou hier' vall die hoorders getree word. Indien die prediker die hoorders op so 'n organiese wyse begelei, kan hy hulle met die ontdekte beginsel tot in hulle situasie(s) bring. Sodoende vind die toepassing in die preek ook op 'n organiese wy'se plaas.

Deur die leiding van die Heilige Gees en die verantwoordelike begeleiding van die prediker un die interaksie kan die hoorders nie onaangeraak van die preek af weggaan nie. Die saaiwerk wat die prediker moet doen, is op 'n verantwoordelike wyse gedoen

\subsubsection{Die gedeelde kennis}

Die geënkodeerde sprekers is goed bekend met die inplisiete hoorders se vaardighede en kennis. Dit is die agtergrondskennis wat deur die implisiete hoorders en geënkodeerde sprekers gedeel word (Leech, 1983:13). Met hierdıe gedeelde 
kennis is die implisiete hoorders in staat om die taaluitings van die geënkodeerde sprekers te kan interpreteer.

Die gedeelde kennis raak die volgende sake: die sosiale sisteem, tradisionele gewoontes en gebruike van ' $n$ kultuur, die spesifieke gespreksituasie en die aard van die verhouding tussen die geënkodeerde sprekers en die implisiete hoorders (Bach \& Harnish, 1979:5). In 'n preek is daar natuurlik ook nog die geloofswaarhede wat gedeelde kennis is. Hierdie geloofswaarhede kan as primêre gedeelde kennis bestempel word. Dié kennis word afgelei uit die gedeelde belydenis van die prediker en die hoorders. Afgesien van dié kennis is die kennis wat die prediker omtrent die individuele hoorders het ook 'n deel van die gedeelde kennis. Indien die prediker nie oor laasgenoemde kennis beskik nie, kan hy nie geldige vrae van die hoorders aan homself stel in die proses van preekmaak nie. Daarom lê die plig by die prediker om die hoorders persoonlik te ken. Deur middel van die gedeelde kennis kan die interaksie en begeleiding op die mees organiese wyse plaasvind. Die gedeelde kennis sluit ook nou aan by die topoi in die preek (kyk \$2.4).

\section{Gevolgtrekking}

Vorster (1988:164) stel tereg dat daar gedurende 'n preek interaksie tussen die prediker en die hoorders plaasvind. Dit stel hy naas al die ander dinge wat 'n preek is. Uit die bespreking van die retoriese situasie en gespreksituasie in ' $n$ preek het dit geblyk dat daar veral interaksie in en met die Skrifteks moet wees. Die doel van die interaksie is egter nie 'n doel op sigself nie, maar dit moet die hoorders (prediker en lidmate) tot 'n ontmoeting met en 'n lewe voor die lewende God bring (Oberholzer, 1990:654).

\section{Bibliografie}

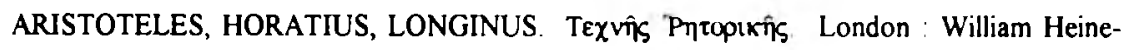
mann. 1947. (Loeb Classical Library.)

ARISTOTELES The Rhetoric of Aristotle. New Jersey : Prentice-Hall Inc 1960 (Vertaal deur L. Cooper.)

BACH, K. \& HARNISH, R.M. 1979. Linguistic Communication and Speech Acts London : MIT Press $327 \mathrm{p}$

BINGLE, P.W. 1986 Táal en vér-taal in die prediking; die homiletiese funksie van taal in die prediking as ' $n$ kommunikasiegebeure Potchefstroom PU vir CHO (Verhandeling Th M) $203 \mathrm{p}$

BYBEL. 1983. Die Bybel: nuwe vertaling Kaapstad Bybelgenootskap van Suid-Afrika

CICERO, Marcus Tullius De Partitione Oratoria London William Heinemann 1948 (Loeb Classical Library.)

COOPER, L

$K y k$

ARISTOTELES

DINGEMANS, G D J 1991. Als hoorder onder de hoorders Hermeneutische Homiletiek Kampen Kok $240 \mathrm{p}$ 
DU TOIT, A B 1992. Retoriek, retoriese analise en prediking In die Skriflig, 26(4):465477.

LEECH, G.N. 1983. Principles of Pragmatics. London : Longman $250 \mathrm{p}$

OBERHOLZER, JP 1990 Ou-Testamentiese perspektiewe op die definisie van die prediking. Hervormde Teologiese Sundies, 46(4) 647-655.

PERELMAN, C \& OLBRECHTS-TYTECA, L 1969. The New Rhetoric A Treatise on Argumentation Notre Dame : University of Notre Dame Press $566 \mathrm{p}$

PIETERSE, H.J.C 1992. Woord en werklikheid in die moderne Praktiese Teologie. In die Skriflig, 26(3):325-335.

QUINTILIANUS, Marcus Fabius De Institutione Oratoria Volumes II London: William Heinemann. 1947. (Loeb Classical Library.)

VAN EEMEREN, F.H \& GROOTENDORST, R 1987. Handbook of Argumentation Theory. Dordrecht : Foris Publications $333 \mathrm{p}$.

VENTER, C.JH 1992. Prakties-Teologiese grondslae van die prediking Praktiese Teologie in Suid-Afrika, 7(1):1-16

VENTER, C.J.H 1993 Basisteoretiese perspektiewe op kommunikasie in die bediening In die Skriflig, 27(2) 247-260

VIOLI, P 1985. Letters (In Van Dijk, T A, ed Discourse and Literature, 3. Amsterdam John Benjamin. pp 149-167)

VORSTER, JN. 1991. The Rhetorical Situation of the Letter to the Romans - an Interactional Approach Pretoria : UP (D.D Proefskrif) 275 p

VORSTER, WS 1988 Oor die Nuwe Testament, venelkunde en prediking Hervormde Teologiese Studies, 44(1) 164-177 
